This study was a University of Birmingham social medicine project. We thank Merieux UK and SmithKline Beecham for funding purchase of the monitor marks; the staff of St Patrick's for their help; the doctors and staff of the participating practices for their cooperation; and Mr S Potter, chief pharmacist at Queen Elizabeth Hospital, for giving background information.
1 Lugosi L, Battersby A. Transport and storage of vaccines in Hungary: the first cold chain monitor study in Europe. Bull World Health Organ 1990;68:431-9. 2 Hunter S. Storage of vaccines in general practice. BMf 1989;299:661-2.

3 Thakker Y, Woods S. Storage of vaccines in the community: weak link in the cold chain? BMIf 1992;304:756-8.

4 Malone-Lee MC. Purchase and supply of vaccines for the childhood immunistion programme. London: NHS Management Executive, 1992. (EL(92)26.)

(Accepted 13 November 1992)

\title{
Risk of vertebral fracture in women with rheumatoid arthritis
}

\author{
T D Spector, G M Hall, E V McCloskey, \\ J A Kanis
}

\section{Department of}

Rheumatology, St

Thomas's Hospital,

London SE1 7EH

T D Spector, consultant

Department of

Rheumatology, St

Bartholomew's Hospital,

London EC1M 6BQ

$\mathrm{G} M$ Hall, senior registrar

Metabolism and Clinical

Biochemistry, University of

Sheffield Medical School,

Sheffield S10 2RX

E V McCloskey, MRC fellow

J A Kanis, professor

Correspondence to:

Dr Spector.

BMF 1993;306:558 rheumatologist

Department of Human

Rheumatoid arthritis commonly affects postmenopausal women, and osteoporosis and resultant fractures may contribute to the morbidity of the condition. ${ }^{\prime}$ No large case-control studies have assessed the rates of vertebral fracture in a standardised manner. We compared women with rheumatoid arthritis with population controls for the presence of vertebral fractures.

\section{Subjects, methods, and results}

The cases were drawn from 191 postmenopausal women aged 45-65 with rheumatoid arthritis who consecutively attended clinics in five London hospitals. All were white, were not taking replacement oestrogens, and had agreed to have their bone density measured before entering a drug study. They were asked if additional radiographs of the spine could be taken, and $149(78 \%)$ agreed. The controls were 713 postmenopausal women aged 45-65 not taking hormone replacements. They were obtained from the age-sex register of a large general practice in London, and those who responded (77\%) were similar to the national average in height, weight, and smoking habits. The socioeconomic status of the women was estimated from their postcode (ACORN classification system).

Radiographs of the women's lateral thoracic and lumbar spine were taken in a standardised manner. They were examined with a semiautomated morphometric technique with high specificity ${ }^{2}$ by a single, blinded observer using a digitising board, and anterior, central, and posterior heights were recorded. The predicted posterior height for each vertebra was calculated from four adjacent vertebrae, and an algorithm compared the ratios with normal ranges of vertebral heights from T4 to L4. A woman was classified as having a fracture if she had at least two minor

Characteristics of postmenopausal women with and without rheumatoid arthritis and with and without vertebral fractures. Figures are means $(S D)$ unless stated otherwise

\begin{tabular}{|c|c|c|c|}
\hline & \multicolumn{2}{|c|}{ Arthrtic women } & \multirow[b]{2}{*}{$\begin{array}{l}\text { Controls } \\
(n=713)\end{array}$} \\
\hline & $\begin{array}{l}\text { With vertebral } \\
\text { fracture }(n=18)\end{array}$ & $\begin{array}{l}\text { Without vertebral } \\
\text { fracture }(n=131)\end{array}$ & \\
\hline Age & $59 \cdot 0(4 \cdot 3)^{\star}$ & $56 \cdot 3(4 \cdot 8)$ & $56 \cdot 0(5 \cdot 2)$ \\
\hline Years since menopause & $10 \cdot 6(7 \cdot 3)$ & $7 \cdot 9(5 \cdot 8)$ & $8 \cdot 6(5 \cdot 8)$ \\
\hline Weight $(\mathrm{kg})$ & $63 \cdot 2(11 \cdot 4)$ & $64 \cdot 9(12 \cdot 1)$ & $67 \cdot 1(11 \cdot 7)$ \\
\hline No (\%) who had undergone hysterectomy & $3(16 \cdot 7)$ & $22(16 \cdot 8)$ & $208(29 \cdot 2)$ \\
\hline No (\%) who had ever smoked & $10(55 \cdot 5)$ & $39(30.9) \dagger$ & $332(46 \cdot 6)$ \\
\hline \multicolumn{4}{|l|}{ Bone mineral density $\left(\mathrm{g} / \mathrm{cm}^{2}\right)$ : } \\
\hline $\mathrm{L}_{1}-\mathbf{L}_{4}$ & $0.89(0.4)$ & $0.92(0 \cdot 16)$ & \\
\hline $\begin{array}{l}\text { Neck of femur } \\
\text { Indicators of disease activity: }\end{array}$ & $0.64(0 \cdot 13)$ & $0.71(0.15)$ & \\
\hline \multicolumn{4}{|l|}{ Indicators of disease activity: } \\
\hline Erythrocyte sedimentation rate & $32 \cdot 9(27 \cdot 6)$ & $33 \cdot 5(24 \cdot 5)$ & \\
\hline Articular index & $9 \cdot 4(8 \cdot 5)$ & $10 \cdot 7(8 \cdot 7)$ & \\
\hline Score on health assessment questionnaire & $1.5(1.0)$ & $1.4(0.9)$ & \\
\hline Duration of disease (years) & $13.9(10 \cdot 7)$ & $11 \cdot 5(9 \cdot 7)$ & \\
\hline
\end{tabular}

${ }^{\star} \mathrm{p}<0.05$ Compared with arthritic women without fracture ( $t$ test).

†No data for five cases. deformities (reduction of two vertebral height ratios by at least $2 \mathrm{SD}$ ) or a single severe deformity (reduction of two vertebral height ratios by at least $3 \mathrm{SD}$ ). The arthritic women were also assessed for disease activity and bone mineral density (at the hip and spine, with a dual energy $x$ ray absorptiometer). Differences between the groups were assessed with the $\chi^{2}$ test for proportions and unpaired $t$ tests (after log transformation of non-normal distributions). Odds ratios were calculated for the risk of fracture in the arthritic women.

The cases and controls were similar in age, years since the menopause, and weight (table). Most controls were from lower to mid-middle class, while the cases had a greater spread of social class. Eighteen arthritic women $(12 \cdot 1 \%)$ had a vertebral fracture compared with $44(6 \cdot 2 \%)$ of the controls (odds ratio $2 \cdot 1$ (95\% confidence interval $1 \cdot 2$ to $3 \cdot 7)$ ).

Among the arthritic women five (28\%) of those with a fracture had used steroids (mean dose $10.8 \mathrm{mg}$ /day for 8.9 years) compared with $46(35 \%)$ of those without a fracture $(7.9 \mathrm{mg} /$ day for 4.3 years $)$. Those with fractures were older $(59.0 v 56.3$ years, $\mathrm{p}=0.02)$ and more likely to have smoked (10/18 (56\%) $v 39 / 126$ $(31 \%), p=0.04)$ (table). No significant differences were found in height, weight, disease activity, duration of disease, socioeconomic class, or years since the menopause. Bone density was lower, but not significantly, in the women with fractures (by $4.9 \%$ in the lumbar spine and by $9.9 \%$ at the hip). Results were similar when only severe fractures were analysed.

\section{Comment}

The rate of vertebral fracture in the women with rheumatoid arthritis was over twice that in the controls. The only other large studies with controls examined hip fractures and rheumatoid arthritis and found odds ratios of 1.5 and $2 \cdot 1 .^{34}$ These results suggest that there is an increased risk of osteoporotic fractures at the spine and hip. In our study bone densities were not uniformly low at all sites, and fractures cannot easily be explained by the use of steroids or disease activity. Ankylosing spondylitis is also associated with increased rates of vertebral fracture. ${ }^{5}$ The prevalence of vertebral fractures in women with rheumatoid arthritis aged over 65 is probably higher than the $12 \%$ found in the younger women in this study, and clinicians should be aware of the possibility of vertebral fractures in all patients with rheumatoid arthritis.

1 Laan FJM, van Riel PLC, van de Putte LBA. Bone mass in patients with rheumatoid arthritis. Ann Rheum Dis 1992;51:826-32.

2 McCloskey EV, Spector TD, Eyres KS, O'Rourke N, Fern DE, Kanis JA. Assessment of vertebral deformity - validation of a new method with high specificity. Osteroporosis Intermational (in press).

3 Hooyman JR, Melton LJ, Nelson AM, O'Fallon MW, Riggs BL. Fractures after rheumatoid arthritis. A population based study. Arthritis Rheum 1984;27:1353-61.

4 Cooper C, Wickham C. Rheumatoid arthritis, corticosteroid therapy and hip fracture. In: Christiansen C, Overgaard K, eds. Osteroporosis 1990 hip fracture. In: Christiansen C, Overg

5 Ralston SH, Urquhart GDK, Brzeski $M$, Sturrock RD. Prevalence of vertebral compression fractures due to osteoporosis in ankylosing spondylitis. $B M \mathcal{J}$
$1990 ; 300: 563-5$.

(Accepted 10 November 1992) 